\title{
Red-light photosensitized cleavage of DNA by (L-lysine)(phenanthroline base)copper(II) complexes $\uparrow$
}

\author{
Ashis K. Patra, Munirathinam Nethaji and Akhil R. Chakravarty* \\ Department of Inorganic and Physical Chemistry, Indian Institute of Science, Bangalore, \\ 560012, India.E-mail: arc@ipc.iisc.ernet.in; Fax: +91-80-23600683
}

Received 5th May 2005, Accepted 1st July 2005

First published as an Advance Article on the web 14th July 2005

Ternary copper(II) complexes $\left[\mathrm{Cu}(\mathrm{L}-\mathrm{lys}) \mathrm{B}\left(\mathrm{ClO}_{4}\right)\right]\left(\mathrm{ClO}_{4}\right)(\mathbf{1 - 4})$, where $\mathrm{B}$ is a heterocyclic base, viz. 2,2'-bipyridine (bpy, 1), 1,10-phenanthroline (phen, 2), dipyrido[3,2-d:2',3'-f]quinoxaline (dpq, 3) and dipyrido[3,2- $\left.a: 2^{\prime}, 3^{\prime}-c\right]$ phenazene $(\mathrm{dppz}, 4)$, are prepared and their DNA binding and photo-induced DNA cleavage activity studied (L-lys $=\mathrm{L}-\mathrm{lysine})$. Complex 2, structurally characterized by X-ray crystallography, shows a square-pyramidal $(4+1)$ coordination geometry in which the N,O-donor L-lysine and N,N-donor heterocyclic base bind at the basal plane and the perchlorate ligand is bonded at the elongated axial site. The crystal structure shows the presence of a pendant cationic amine moiety $-\left(\mathrm{CH}_{2}\right)_{4} \mathrm{NH}_{3}{ }^{+}$of L-lysine. The one-electron paramagnetic complexes display a d- $\mathrm{d}$ band in the range of 598-762 $\mathrm{nm}$ in $\mathrm{DMF}$ and exhibit cyclic voltammetric response due to $\mathrm{Cu}(\mathrm{II}) / \mathrm{Cu}$ (I) couple in the range of 0.07 to $-0.20 \mathrm{~V} v s$. SCE in DMF-Tris- $\mathrm{HCl}$ buffer. The complexes having phenanthroline bases display good binding propensity to the calf thymus DNA giving an order: $\mathbf{4}(\mathrm{dppz})>\mathbf{3}(\mathrm{dpq})>\mathbf{2}$ (phen) $\gg \mathbf{1}$ (bpy). Control cleavage experiments using pUC19 supercoiled DNA and distamycin suggest major groove binding for the dppz and minor groove binding for the other complexes. Complexes 2-4 show efficient DNA cleavage activity on UV (365 nm) or visible light (694 $\mathrm{nm}$ ruby laser) irradiation via a mechanistic pathway involving formation of singlet oxygen as the reactive species. The amino acid L-lysine bound to the metal shows photosensitizing effect at red light, while the heterocyclic bases are primarily DNA groove binders. The dpq and dppz ligands display red light-induced photosensitizing effects in copper-bound form.

\section{Introduction}

Current research interest in the development of the chemistry of new synthetic organic and metalloorganic reagents with an ability to bind and cleave double stranded DNA under physiological conditions stems from their potential utility as diagnostic agents in medicinal applications, as probes for conformational studies of nucleic acid, as footprinting agents and for genomic research. ${ }^{1-15}$ The DNA cleavage reactions are generally targetted towards its basic constituents, viz. heterocyclic base, sugar and phosphate. While the reactions targetted to the phosphodiester linkage proceed via hydrolytic cleavage pathways leading to the formation of fragments that could be religated through enzymatic processes, the DNA cleavage by nucleobase oxidation and/or degradation of sugar by abstraction of sugar hydrogen atom(s) follows oxidative reaction pathway. Again, among different methodologies adopted to cleave DNA by an oxidative process, the one based on photo-irradiation with visible light of wavelength in the phototherapeutic window of ca. $620-850 \mathrm{~nm}$ has gained importance for their relevance to the antitumor reagents used in the photodynamic therapy (PDT) of cancer. ${ }^{16-20}$ PDT is a non-invasive therapeutic treatment of cancer in which a photosensitizing drug on photo-excitation at red light transfers its excited state energy to molecular oxygen in a type-II process forming reactive singlet oxygen species that causes oxidative cellular damage. The porphyrinic species Photofrin ${ }^{\circledR}$ is currently used as an anticancer PDT drug which is active on $630 \mathrm{~nm}$ photo-irradiation. We are involved in the development of the chemistry of non-porphyrinic copper-based complexes as new photoactive DNA cleaving agents. ${ }^{21-25}$

In our present work, we planned to synthesize ternary copper(II) complexes containing a bioessential $\alpha$-amino acid Llysine as a potential photosensitizer in the metal bound form and

$\dagger$ Electronic supplementary information (ESI) available: Unit cell packing diagram, DNA binding plots, gel electrophoresis diagrams (Figs. S1-S5). See http://dx.doi.org/10.1039/b506310h
$\mathrm{N}, \mathrm{N}$-donor heterocyclic bases as DNA groove binders. Amino acid and peptide-based transition metal complexes without having any photoactivatable group have previously been used as synthetic hydrolases and "chemical nucleases". ${ }^{26-28}$ Recent reports have shown that amino acids and peptides tethered with photoactive organic molecules are cleaver of DNA on irradiation with UV light and there is a growing interest in the use of covalently bound amino acids/peptides(A)-DNA intercalator(B) conjugates of the type "A-B" (I) for their potential utility as models for naturally occurring antibiotics in cancer therapy (Scheme 1). ${ }^{29-31}$ DNA intercalators thiazole orange conjugated to synthetic dipeptides are known to show DNA cleavage at $365 \mathrm{~nm} \cdot{ }^{29}$ Similarly, L-lysine derivatives with the 1,8-naphthalimide chromophore display DNA photocleavage at UV light of $320-380 \mathrm{~nm} .{ }^{30}$ There is a recent report on lysineenediyne conjugates that photochemically trigger the doublestrand cleavage of duplex-DNA using UV light. ${ }^{31}$ It is likely that the high energy associated with the ${ }^{3}\left(n-\pi^{*}\right)$ and/or ${ }^{3}(\pi-$ $\left.\pi^{*}\right)$ photoexcitations for such organic conjugates (I) could be the reason for observing DNA cleavage at only UV light thus making them unsuitable for PDT applications.

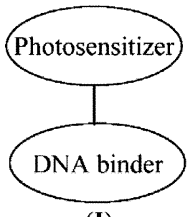

(I)

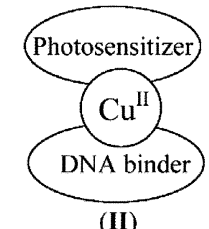

(II)

\section{L-Lysine}

Phenanthroline

base

Scheme 1 Organic photosensitizer-DNA binder conjugate (I) and the two moieties bound to a copper(II) center (II).

We have probed the effect of a transition metal like copper(II) ion on the photoexcitation wavelength in a ternary structure "A-CuII-B" (II) having the amino acid (A) and the DNA binder (B) covalently bound to the metal with an aim to achieve visible light-induced DNA cleavage activity mediated by the charge 
Table 1 Selected physicochemical data for the complexes $\left[\mathrm{Cu}(\mathrm{L}-\mathrm{lys}) \mathrm{B}\left(\mathrm{ClO}_{4}\right)\right]\left(\mathrm{ClO}_{4}\right)(\mathbf{1 - 4})$

\begin{tabular}{|c|c|c|c|c|}
\hline Complex & 1 & 2 & 3 & 4 \\
\hline $\mathrm{IR}^{a}:\left[v\left(\mathrm{ClO}_{4}^{-}\right) / \mathrm{cm}^{-1}\right]$ & $1138,1112,1083$ & $1139,1115,1083$ & $1142,1111,1082$ & $1140,1110,1088$ \\
\hline d-d band: $\lambda_{\max } / \mathrm{nm}\left(\varepsilon / \mathrm{dm}^{3} \mathrm{~mol}^{-1} \mathrm{~cm}^{-1}\right)^{b}$ & $598(70)$ & $612(75)$ & $618(135)$ & $762(800)$ \\
\hline Cyclic voltammetry: $E_{1 / 2} / \mathrm{V}\left(\Delta E_{\mathrm{p}} / \mathrm{mV}\right)^{c}$ & $-0.205(250)$ & $-0.007(160)$ & $0.073(150)$ & $0.094(188)$ \\
\hline$\Lambda_{\mathrm{M}}{ }^{d} / \Omega^{-1} \mathrm{~cm}^{2} \mathrm{~mol}^{-1}$ & 132 & 135 & 65 & 52 \\
\hline$\mu_{\mathrm{eff}}{ }^{e} / \mu_{\mathrm{B}}$ & 1.87 & 1.94 & 1.88 & 1.85 \\
\hline
\end{tabular}

${ }^{a} \mathrm{KBr}$ phase. ${ }^{b} \mathrm{In} \mathrm{DMF} .{ }^{c} \mathrm{Cu}(\mathrm{II}) / \mathrm{Cu}(\mathrm{I})$ couple in DMF-Tris buffer $(1: 4 \mathrm{v} / \mathrm{v}) . E_{1 / 2}=0.5\left(E_{\mathrm{pa}}+E_{\mathrm{pc}}\right), \Delta E_{\mathrm{p}}=E_{\mathrm{pa}}-E_{\mathrm{pc}}$, where $E_{\mathrm{pa}}$ and $E_{\mathrm{pc}}$ are the anodic and cathodic peak potentials, respectively. ${ }^{d}$ In DMF. ${ }^{e} \mu_{\text {eff }}$ for solid at $298 \mathrm{~K}$.

transfer and low-energy $\mathrm{d}-\mathrm{d}$ band of the metal (Scheme 1). Our recent work on ternary L-methionine copper(II) complexes having heterocyclic bases has shown the effect of the metal ion in cleaving DNA on red-light irradiation. The L-methionine ligand is, however, found to be a poor photosensitizer in comparison to the dipyridoquinoxaline and dipyridophenazine ligands. ${ }^{32}$ Considering potential photosensitizing ability and the biological importance of $\alpha$-amino acid L-lysine (L-lys), we have prepared a new series of ternary copper(II) complexes $\left[\mathrm{Cu}(\mathrm{L}-\mathrm{lys}) \mathrm{B}\left(\mathrm{ClO}_{4}\right)\right]\left(\mathrm{ClO}_{4}\right)$ (1-4), where phenanthroline bases 1,10-phenanthroline (phen, 2), dipyrido[3,2-d:2', $\left.3^{\prime}-f\right]$ quinoxaline (dpq, 3) and dipyrido[3,2$\left.a: 2^{\prime}, 3^{\prime}-c\right]$ phenazene $(\mathrm{dppz}, 4)$ are efficient DNA groove binders (Scheme 2). We have observed significant cleavage of DNA by 2 4 on irradiation with UV and red light. The results are of importance considering the lack of cleavage activity of the amino acidintercalator organic conjugates or bioorganometallic species such as $\left[\left(\eta^{5}-\mathrm{C}_{5} \mathrm{Me}_{5}\right) \operatorname{Ir}(\text { amino acid })(\text { dipyridophenazine })\right]^{n+}(n=$ $1-3)$ in the phototherapeutic spectral window. ${ }^{29-31,33}$<smiles>NCCCCC1NC2(OC(=O)O)C(O1)N1CCN2CC1</smiles>

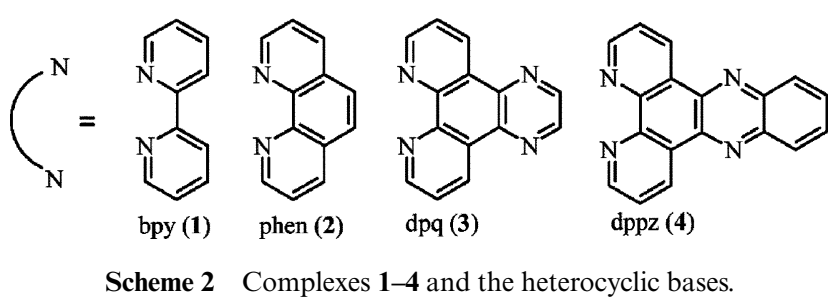

\section{Results and discussion}

\section{Synthesis and general aspects}

We are interested to develope the chemistry of ternary copper(II) complexes of the type [ $\alpha$-amino acid $) \mathrm{Cu}^{\mathrm{II}}(\mathrm{DNA}$ binder heterocyclic base) $]^{n+}$ for the photo-induced cleavage of DNA at red light. In the present work, we have chosen amino acid L-lysine as a potential photoactivator with an alkyl chain that terminates in a cationic amino group. Our choice for planar phenanthroline bases is based on their good binding propensity to DNA as well as for their photosensitizing abilities in the presence of quinoxaline or phenazine moiety that could generate photo-excited ${ }^{3}\left(n-\pi^{*}\right)$ and $/$ or $^{3}\left(\pi-\pi^{*}\right)$ state $(\mathrm{s})$ causing activation of molecular oxygen in the DNA cleavage reactions. ${ }^{34}$ The ternary complexes are synthesized in good yield by reacting the in situ generated sodium salt of L-lysine with $\mathrm{Cu}\left(\mathrm{ClO}_{4}\right)_{2} \cdot 6 \mathrm{H}_{2} \mathrm{O}$ and the heterocyclic base. They are isolated as perchlorate salt of formulation $\left[\mathrm{Cu}(\mathrm{L}-\mathrm{lys}) \mathrm{B}\left(\mathrm{ClO}_{4}\right)\right]\left(\mathrm{ClO}_{4}\right)(\mathbf{1 - 4})$, where $\mathrm{B}$ is the N,N-donor heterocyclic base (bpy, 1; phen, 2; dpq, 3; dppz, 4) (Scheme 2). We have also prepared known ternary copper(II) complexes of L-phenylalanine and L-methionine for control DNA cleavage experiments to compare the photosensitizing abilities of different amino acids. ${ }^{32,35}$ The complexes are characterized from their analytical and physicochemical data (Table 1). The one-electron paramagnetic complexes exhibit a broad $\mathrm{d}-\mathrm{d}$ band in the range of $598-618 \mathrm{~nm}$ for $\mathbf{1 - 3}$ and at $762 \mathrm{~nm}$ for the dppz complex in DMF (Fig. 1(a)). The observation of a visible band at a significantly low energy and higher molar absorptivity for the dppz complex could be due to structural difference of $\mathbf{4}$ from the others in the presence of an extended aromatic moiety in dppz. A similar low energy visible band at $707 \mathrm{~nm}$ is known for $\left[\mathrm{Cu}^{\mathrm{II}}(\mathrm{dppz})_{2} \mathrm{Cl}\right] \mathrm{Cl}^{36}{ }^{36}$ The dpq and dppz complexes show a moderately strong band near $440 \mathrm{~nm}$ possibly due to $n-\pi^{*}$ transition involving the quinoxaline or phenazine moieties as this band is not observed in the bpy and phen complexes. The complexes display quasireversible cyclic voltammetric response assignable to the $\mathrm{Cu}(\mathrm{II}) / \mathrm{Cu}(\mathrm{I})$ couple in the range of 0.07 to $-0.20 \mathrm{~V}$ (SCE) in DMF-Tris- $\mathrm{HCl}$ buffer showing greater stability of the $\mathrm{Cu}(\mathrm{I})$ state in the dppz complex. The poor reversibility of the redox process, evidenced from the high $\Delta E_{\mathrm{p}}$ values, is due to structural rigidity of the ternary complexes (Fig. 1(b)). The infrared spectra of the complexes display the presence of copper-bound and lattice perchlorates. While the dpq and dppz complexes show 1: 1 electrolytic conductivity in DMF, the bpy and phen complexes exhibit higher conductivity values possibly due to dissociation of the copperbound perchlorate ligand.
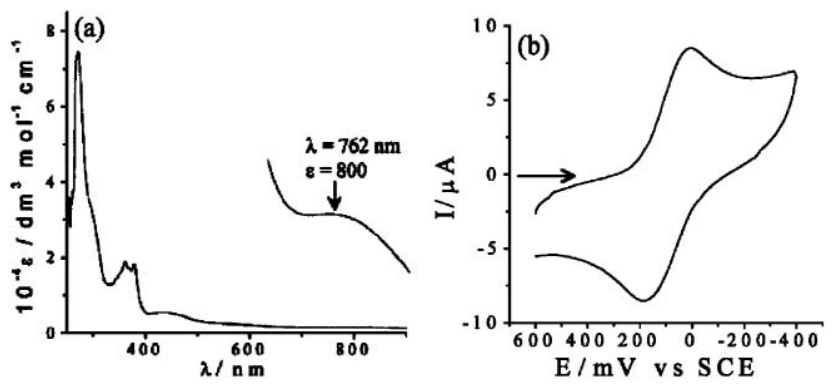

Fig. 1 (a) Electronic spectrum of $\mathbf{4}$ in DMF. (b) Cyclic voltammogram of 4 in DMF-Tris buffer at a scan rate of $50 \mathrm{mV} \mathrm{s}^{-1}$.

\section{Crystal structure}

The phen complex $2 \cdot 0.5 \mathrm{H}_{2} \mathrm{O}$ has been characterized from single-crystal X-ray diffraction study. It crystallizes in noncentrosymmetric $P 2_{1} 2_{1} 2_{1}$ space group of orthorhombic crystal system having two independent molecules in the crystallographic asymmetric unit. The crystal structure shows monocationic nature of the complex having chelating bidentate L-lysine with the $S$-configuration of the chiral carbon atom, the presence of an N,N-donor 1,10-phenanthroline in a square-pyramidal $(4+$ 1) geometry and an weakly bound axial perchlorate ligand. The perspective view of the two molecules is shown in Fig. 2 and relevant bond distances and angles are given in Table 2. The average trigonal distortion parameter $(\tau)$ value in the structure is $0.023 .{ }^{37}$ The average $\mathrm{Cu}-\mathrm{O}$ (L-lys), $\mathrm{Cu}-\mathrm{N}$ (L-lys), $\mathrm{Cu}-\mathrm{N}$ (phen) and $\mathrm{Cu}-\mathrm{O}\left(\mathrm{ClO}_{4}{ }^{-}\right)$distances are 1.936[5], 1.989[6], 1.995[5] and $2.530[5] \AA$, respectively. The alkyl chain of the cationic amino group $-\left(\mathrm{CH}_{2}\right)_{4} \mathrm{NH}_{3}{ }^{+}$remains as a pendant moiety. There are two 
Table 2 Selected bond distances $(\AA)$ and angles $\left(^{\circ}\right)$ for $2 \cdot 0.5 \mathrm{H}_{2} \mathrm{O}$ with esds in the parenthesis

\begin{tabular}{lrlr}
\hline \multicolumn{3}{l}{ Molecule A } & \multicolumn{3}{l}{ Molecule B } \\
\hline $\mathrm{Cu}(1)-\mathrm{O}(1)$ & $1.938(4)$ & $\mathrm{Cu}(2)-\mathrm{O}(3)$ & $1.934(5)$ \\
$\mathrm{Cu}(1)-\mathrm{N}(1)$ & $2.004(5)$ & $\mathrm{Cu}(2)-\mathrm{N}(5)$ & $2.018(6)$ \\
$\mathrm{Cu}(1)-\mathrm{N}(2)$ & $1.987(5)$ & $\mathrm{Cu}(2)-\mathrm{N}(6)$ & $1.970(6)$ \\
$\mathrm{Cu}(1)-\mathrm{N}(3)$ & $1.976(5)$ & $\mathrm{Cu}(2)-\mathrm{N}(7)$ & $2.002(6)$ \\
$\mathrm{Cu}(1)-\mathrm{O}(11)$ & $2.496(5)$ & $\mathrm{Cu}(2)-\mathrm{O}(21)$ & $2.565(6)$ \\
& & & \\
$\mathrm{O}(1)-\mathrm{Cu}(1)-\mathrm{N}(3)$ & $84.5(2)$ & $\mathrm{O}(3)-\mathrm{Cu}(2)-\mathrm{N}(7)$ & $84.8(2)$ \\
$\mathrm{O}(1)-\mathrm{Cu}(1)-\mathrm{N}(2)$ & $94.3(2)$ & $\mathrm{N}(6)-\mathrm{Cu}(2)-\mathrm{N}(5)$ & $82.6(2)$ \\
$\mathrm{O}(1)-\mathrm{Cu}(1)-\mathrm{N}(1)$ & $171.9(2)$ & $\mathrm{O}(3)-\mathrm{Cu}(2)-\mathrm{N}(6)$ & $94.9(2)$ \\
$\mathrm{N}(2)-\mathrm{Cu}(1)-\mathrm{N}(1)$ & $82.9(2)$ & $\mathrm{N}(6)-\mathrm{Cu}(2)-\mathrm{N}(7)$ & $172.9(3)$ \\
$\mathrm{N}(3)-\mathrm{Cu}(1)-\mathrm{N}(1)$ & $99.1(2)$ & $\mathrm{N}(7)-\mathrm{Cu}(2)-\mathrm{N}(5)$ & $98.5(2)$ \\
$\mathrm{N}(3)-\mathrm{Cu}(1)-\mathrm{N}(2)$ & $173.8(2)$ & $\mathrm{O}(3)-\mathrm{Cu}(2)-\mathrm{N}(5)$ & $172.0(2)$ \\
$\mathrm{N}(1)-\mathrm{Cu}(1)-\mathrm{O}(11)$ & $88.3(2)$ & $\mathrm{N}(5)-\mathrm{Cu}(2)-\mathrm{O}(21)$ & $84.9(3)$ \\
$\mathrm{N}(2)-\mathrm{Cu}(1)-\mathrm{O}(11)$ & $89.2(2)$ & $\mathrm{N}(6)-\mathrm{Cu}(2)-\mathrm{O}(21)$ & $94.1(2)$ \\
$\mathrm{N}(3)-\mathrm{Cu}(1)-\mathrm{O}(11)$ & $85.0(2)$ & $\mathrm{N}(7)-\mathrm{Cu}(2)-\mathrm{O}(21)$ & $92.9(3)$ \\
$\mathrm{O}(1)-\mathrm{Cu}(1)-\mathrm{O}(11)$ & $99.3(2)$ & $\mathrm{O}(3)-\mathrm{Cu}(2)-\mathrm{O}(21)$ & $87.7(2)$ \\
\hline
\end{tabular}

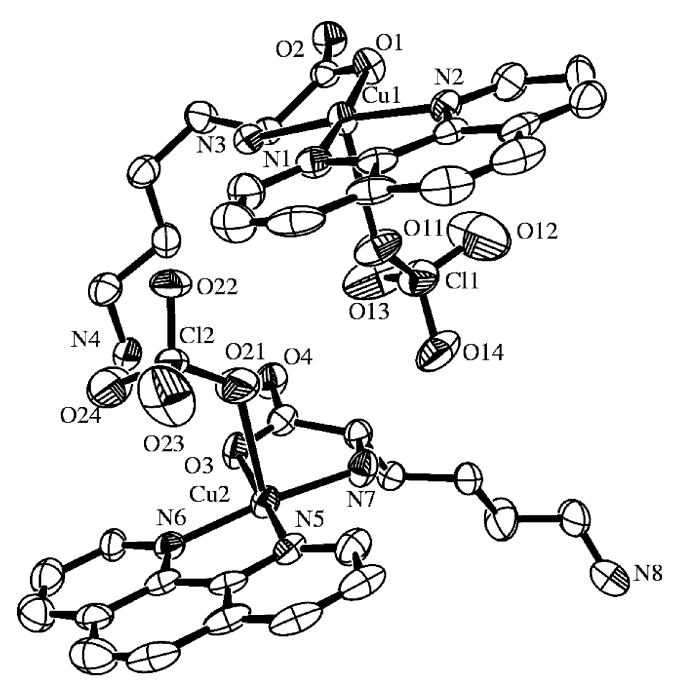

Fig. 2 The ORTEP views of the cationic complexes belonging to two independent molecules of $2 \cdot 0.5 \mathrm{H}_{2} \mathrm{O}$ showing the atom labelling scheme for the metal and hetero-atoms with $30 \%$ probability thermal ellipsoids.

lattice perchlorate anions along with a solvent water molecule in the crystallographic asymmetric unit. The water molecule is involved in the hydrogen bonding interactions with the terminal cationic amine moiety of L-lysine giving a $\mathrm{O} \cdots \mathrm{N}$ distance of $\sim 2.7 \AA$. The lattice perchlorate anions could have weak contacts with the copper(II) atoms in the solid state structure as they are located at $c a$. $2.7 \AA$ from the vacant axial sites of the metals.

\section{DNA binding and chemical nuclease properties}

The mode and propensity of binding of the complexes to calf thymus (CT) DNA are studied by different techniques (Table 3). An intercalative binding of a complex to DNA generally results in hypochromism along with a red shift (bathochromic shift) of the electronic spectral band. ${ }^{38}$ The extent of the hypochromism gives a measure of the strength of the intercalative binding/interaction. The phen complex $\mathbf{2}$ having

Table 3 DNA binding parameters for the complexes 1-4

\begin{tabular}{lllll}
\hline Complex & $K_{\mathrm{b}} / \mathrm{M}^{-1}$ & $K_{\mathrm{app}} / \mathrm{M}^{-1}$ & $\Delta T_{\mathrm{m}} /{ }^{\circ} \mathrm{C}$ & $\% \Delta \theta_{275^{a}}$ \\
\hline $\mathbf{1}$ & $1.36 \times 10^{2}$ & - & 1 & 4.3 \\
$\mathbf{2}$ & $6.14 \times 10^{3}$ & $1.05 \times 10^{5}$ & 4 & 11.1 \\
$\mathbf{3}$ & $8.56 \times 10^{3}$ & $3.65 \times 10^{5}$ & 5 & 12.6 \\
$\mathbf{4}$ & $2.45 \times 10^{4}$ & $5.33 \times 10^{5}$ & 7 & 14.0
\end{tabular}

${ }^{a} \Delta \theta_{275}$, change in molecular ellipticity at $275 \mathrm{~nm}$ planar aromatic rings is found to show a minor bathochromic shift of $c a$. $4 \mathrm{~nm}$ along with significant hypochromicity of $\sim 47 \%$. Similar spectral changes are also observed for the dpq and dppz complexes. The intrinsic binding constants $\left(K_{\mathrm{b}}\right)$ with CTDNA that are determined from the decay of the spectral band absorbance show significant binding propensity of $\mathbf{4}$ having a dppz ligand with its extended fused aromatic rings. The bpy complex 1 does not show any significant binding to CTDNA. The apparent binding constants $\left(K_{\text {app }}\right)$ of the complexes to the CT-DNA have been determined by fluorescence spectral method using the emission intensity of ethidium bromide (EB) as a probe. EB in a buffer medium shows reduced emission intensity due to quenching by the solvent molecules. It, however, exhibits significantly enhanced emission intensity when bound to DNA. Binding of the complex to DNA could displace EB thus decreasing its emission intensity or quenching could take place due to the presence of the paramagnetic copper(II) complex in a DNA bound form. We have measured the reduction of the emission intensity of EB at different complex concentration $(25-125 \mu \mathrm{M})$. The $K_{\text {app }}$ has been calculated from the equation: $K_{\mathrm{EB}}[\mathrm{EB}]=K_{\text {app }}$ [complex], where $K_{\mathrm{EB}}$ is $1.0 \times 10^{7} \mathrm{M}^{-1}$ and the concentration of EB as $1.3 \mu \mathrm{M}\left([\mathrm{CT}\right.$-DNA] $=300 \mu \mathrm{M}){ }^{39}$ The thermal denaturation studies show a change in the DNA-melting temperature $\left(\Delta T_{\mathrm{m}}\right)$ of $\sim 5{ }^{\circ} \mathrm{C}$ (Fig. 3(b)). ${ }^{40}$ Circular dichroic spectral studies show no significant change of the CD bands at 275 and $248 \mathrm{~nm}$ for the base stacking and right-handed helicity respectively (Fig. 3(a)). The results indicate primarily electrostatic and/or groove binding nature of the complexes without causing any change of conformation of the DNA used. ${ }^{41}$
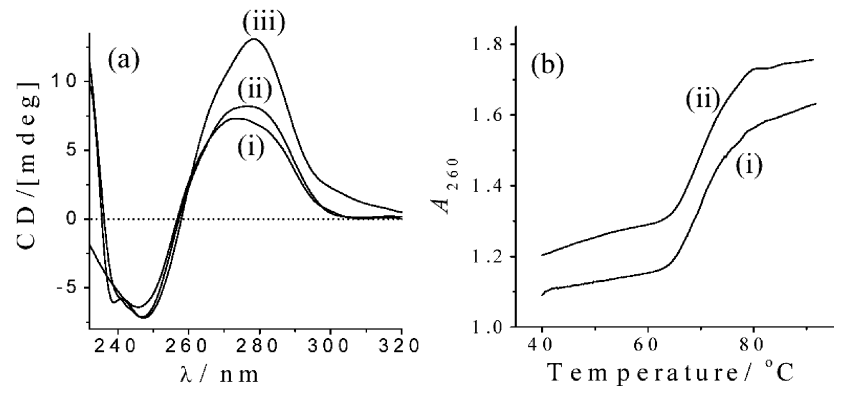

Fig. 3 (a) Circular dichroism spectra of CT-DNA in the absence (i) and presence of complex 2 (ii) and $\left[\mathrm{Cu}(\mathrm{phen})_{2}\left(\mathrm{H}_{2} \mathrm{O}\right)\right]^{2+}$ (iii) at $1 / R=$ 0.0625 , where $R=[\mathrm{NP}] /[\mathrm{Cu}]$ in Tris- $\mathrm{HCl}$ buffer medium (pH 7.2). (b) DNA-melting experiments ([CT-DNA] $=150 \mu \mathrm{M})$ in absence (i) and presence of $2(75 \mu \mathrm{M})$ (ii) in phosphate buffer $(\mathrm{pH}=6.85$, [complex] $=$ $5 \mathrm{mM})$.

The "chemical nuclease" activity of the complexes $(100 \mu \mathrm{M}$ in $2 \mu \mathrm{L} \mathrm{DMF}$ ) in the presence of a reducing agent 3mercaptopropionic acid (MPA, $5 \mathrm{mM}$ ) has been studied by gel electrophoresis using supercoiled (SC) pUC19 DNA $(0.5 \mu \mathrm{g})$ in $50 \mathrm{mM}$ Tris- $\mathrm{HCl} / 50 \mathrm{mM} \mathrm{NaCl}$ buffer (14 $\mu \mathrm{L}, \mathrm{pH}$ 7.2) (Fig. 4). The chemical nuclease activity follows the order: $4>\mathbf{3}>\mathbf{2} \gg$ 1. Control experiments using MPA or the ternary complex alone do not show any apparent cleavage of DNA. The bpy

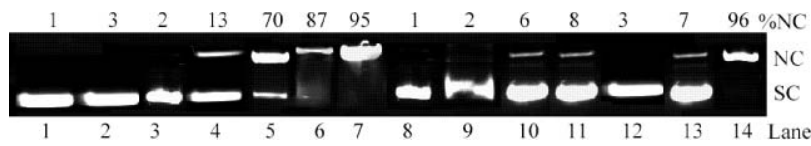

Fig. 4 Gel electrophoresis diagram showing the cleavage of SC pUC19 DNA $(0.5 \mu \mathrm{g})$ by complexes $\mathbf{1 - 4}(100 \mu \mathrm{M})$ in the presence of MPA (5 mM): lane 1, DNA control; lane 2, DNA + MPA; lane 3, DNA + 4; lane 4, DNA + 1 + MPA; lane 5, DNA + 2 + MPA; lane 6, DNA + 3+ $\mathrm{MPA}$; lane 7, DNA + $\mathbf{4}+\mathrm{MPA}$; lane 8 , DNA + DMSO $(4 \mu \mathrm{L})+\mathbf{4}+$ MPA; lane 9, DNA + catalase (1 unit) + $4+$ MPA; lane 10, DNA + $\mathrm{KI}(100 \mu \mathrm{M})+\mathbf{3}+\mathrm{MPA}$; lane 11 , DNA + mannitol $(100 \mu \mathrm{M})+\mathbf{3}+$ MPA; lane 12, DNA + distamycin $(100 \mu \mathrm{M})+2$ + MPA; lane 13, DNA + distamycin $(100 \mu \mathrm{M})+3+$ MPA; lane 14, DNA + distamycin $(100 \mu \mathrm{M})+\mathbf{4}+$ MPA. 
Table 4 Photoinduced DNA (SC pUC19, $0.5 \mu \mathrm{g}$ ) cleavage data ${ }^{a}$ for the complexes 1-4 at 365 and $694 \mathrm{~nm}$

\begin{tabular}{|c|c|c|c|c|c|c|}
\hline No. & Reaction conditions & {$[\mathrm{M}] / \mu \mathrm{M}$} & $\lambda / \mathrm{nm}$ & $t^{b}$ & Form-I ( $\%)$ & Form-II ( $\%)$ \\
\hline 1 & DNA control & - & 365 & 60 & 97 & 3 \\
\hline 2 & $\mathrm{DNA}+1$ & 25 & 365 & 60 & 96 & 4 \\
\hline 3 & $\mathrm{DNA}+\mathbf{2}$ & 25 & 365 & 60 & 44 & 56 \\
\hline 4 & $\mathrm{DNA}+\mathbf{2}$ & 50 & 365 & 15 & 24 & 76 \\
\hline 5 & $\mathrm{DNA}+\mathbf{3}$ & 25 & 365 & 60 & 30 & 70 \\
\hline 6 & $\mathrm{DNA}+4$ & 25 & 365 & 60 & 3 & 97 \\
\hline 7 & $\mathrm{DNA}+\mathrm{L}-\mathrm{lys}^{c}$ & - & 365 & 60 & 95 & 5 \\
\hline 8 & $\mathrm{DNA}+\mathrm{dpq}^{c}$ & - & 365 & 60 & 89 & 11 \\
\hline 9 & $\mathrm{DNA}+\mathrm{dppz}^{c}$ & - & 365 & 60 & 92 & 8 \\
\hline 10 & $\mathrm{DNA}+\mathrm{NaN}_{3}{ }^{d}+\mathbf{2}$ & 50 & 365 & 15 & 95 & 5 \\
\hline 11 & $\mathrm{DNA}+\mathrm{D}_{2} \mathrm{O}^{e}+2$ & 50 & 365 & 15 & 4 & 96 \\
\hline 12 & $\mathrm{DNA}+\mathrm{DMSO}^{f}+\mathbf{2}$ & 50 & 365 & 15 & 25 & 75 \\
\hline 13 & DNA control & - & 694 & 60 & 95 & 5 \\
\hline 14 & $\mathrm{DNA}+\mathbf{2}$ & 50 & 694 & 60 & 38 & 62 \\
\hline 15 & $\mathrm{DNA}+\mathbf{3}$ & 50 & 694 & 60 & 7 & 93 \\
\hline 16 & $\mathrm{DNA}+4$ & 50 & 694 & 60 & 8 & $92^{g}$ \\
\hline
\end{tabular}

${ }^{a}$ Form-I and form-II are supercoiled and nicked circular forms of DNA. ${ }^{b} t$, exposure time in minute. ${ }^{c} 25 \mu \mathrm{M} .{ }^{d} 100 \mu \mathrm{M} .{ }^{e} 14 \mu \mathrm{L} .{ }^{f} 4 \mu \mathrm{L} .{ }^{g}$ Contains $8 \%$ of linear form (Form-III) of DNA.

complex 1 is cleavage inactive. To determine the groove binding preference of the complexes, the DNA cleavage experiments are performed in the presence of minor groove binder distamycin. While distamycin does not show any inhibition of cleavage for the dppz complex, it inhibits the cleavage for the dpq and phen complexes. The results suggest major groove binding for the dppz complex and minor groove binding for the other complexes. Control experiments show that hydroxyl radical scavenger catalase or DMSO inhibits the cleavage. The singlet oxygen quencher sodium azide does not show any inhibition. The pathways involved in the DNA cleavage are believed to be similar to those proposed by Sigman and co-workers for the "chemical nuclease" activity of bis(phen)copper species (Scheme 3). ${ }^{42-44}$ The cleavage efficiencies of the dpq and dppz complexes are expected to differ as they show different groove binding preference.

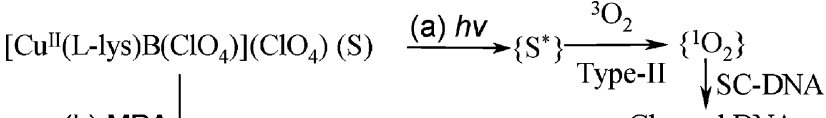

$$
\begin{aligned}
& \text { (b) MPA Cleaved DNA } \\
& \stackrel{\mathrm{C}^{2}}{\stackrel{\mathrm{O}_{2}}{\longrightarrow}}\left\{\mathrm{HO}^{*}\right\} \stackrel{\text { SC-DNA }}{ } \uparrow
\end{aligned}
$$

Scheme 3 Mechanistic pathways for the cleavage of DNA on photoirradiation (a) or in the presence of MPA under dark condition (b).

\section{DNA photocleavage activity}

The photo-induced DNA (SC pUC19, $0.5 \mu \mathrm{g}$ ) cleavage experiments were done in UV ( $365 \mathrm{~nm}, 12 \mathrm{~W}$ ) and visible (694 $\mathrm{nm}$ ruby laser) light using 25 and $50 \mu \mathrm{M}$ concentration of the complexes in absence of any external additive such as MPA. Selected cleavage data are given in Table 4. The extent of DNA cleavage at different exposure time is shown in Fig. 5. The gel electrophoresis diagram for the control experiments is displayed in Fig. 6. The bpy complex does not show any photonuclease activity at $365 \mathrm{~nm}$. The dppz complex is most active and displays $\sim 97 \%$ conversion of the SC (form I) to its nicked circular form (NC, form II) of DNA on 60 min exposure time using a complex concentration of $25 \mu \mathrm{M}$. The dpq complex also shows significant cleavage of SC DNA under similar experimental conditions. Control experiments using the ternary complex under dark condition or L-lys alone at $365 \mathrm{~nm}$ do not show any apparent cleavage of SC DNA. The heterocyclic bases dpq and dppz $(25 \mu \mathrm{M})$ alone are cleavage inactive at $365 \mathrm{~nm}$. The amino acid L-lys in metal bound form acts as a photosensitizer as the L-phenylalanine analogue $\left[\mathrm{Cu}(\mathrm{L}-\mathrm{phe})(\mathrm{dppz})\left(\mathrm{H}_{2} \mathrm{O}\right)\right]^{+}$shows no apparent photoinduced DNA cleavage activity (Fig. 7). It has been observed that L-lysine ternary complexes containing phenanthroline bases

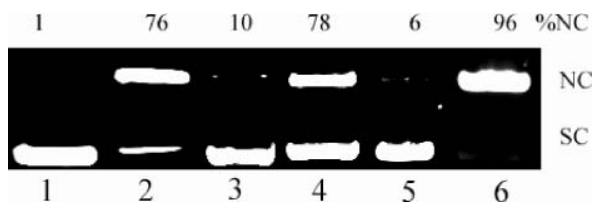

Fig. 6 Gel electrophoresis diagram displaying the photocleavage of SC pUC19 DNA $(0.5 \mu \mathrm{g})$ at $365 \mathrm{~nm}$ by $2(50 \mu \mathrm{M})$ in the presence of different additives for $15 \mathrm{~min}$ exposure time in $50 \mathrm{mM}$ Tris $-\mathrm{HCl} / \mathrm{NaCl}$ buffer (pH 7.2): lane 1, DNA control; lane 2, DNA + 2; lane 3, DNA + $\mathrm{NaN}_{3}(100 \mu \mathrm{M})+2(50 \mu \mathrm{M})$; lane 4 , DNA + DMSO $(4 \mu \mathrm{L})+\mathbf{2}$; lane 5 , DNA + 2 (under argon); lane 6, DNA + $\mathrm{D}_{2} \mathrm{O}(14 \mu \mathrm{L})+2$.
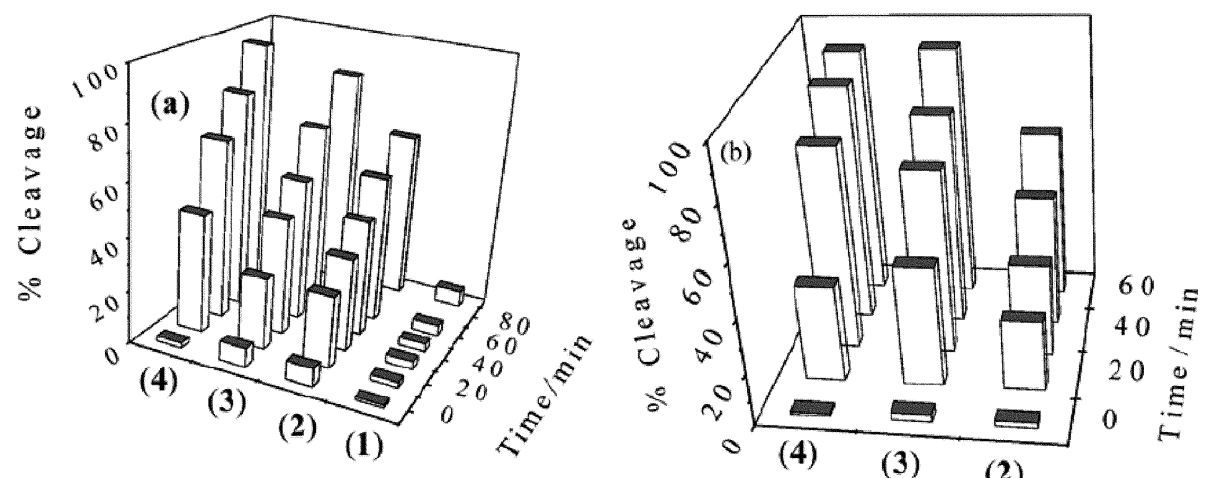

Fig. 5 Cleavage of SC DNA $(0.5 \mu \mathrm{g})$ by the complexes $\mathbf{1 - 4}$ on exposure to (a) UV light of $365 \mathrm{~nm}$ wavelength ([complex] $=25 \mu \mathrm{M})$ and (b) $694 \mathrm{~nm}$ ruby laser $([$ complex $]=50 \mu \mathrm{M})$. 


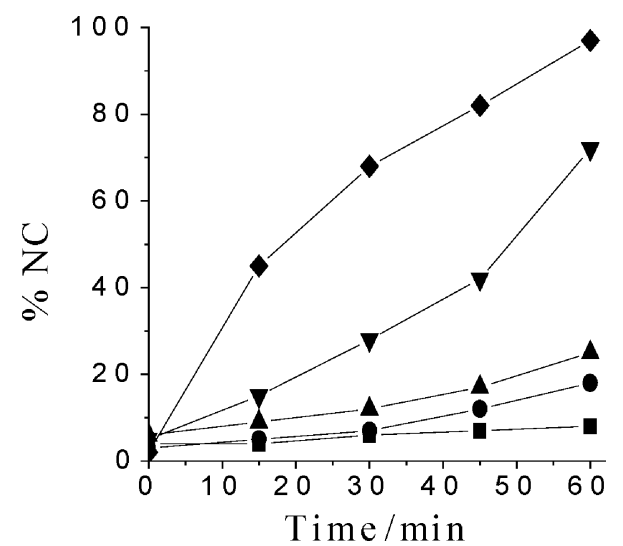

Fig. 7 The extent of light-induced cleavage of SC DNA $(0.5 \mu \mathrm{g})$ by $\mathrm{Cu}\left(\mathrm{NO}_{3}\right)_{2} \cdot 2 \mathrm{H}_{2} \mathrm{O}(\boldsymbol{\square})$; dppz alone $(\bullet) ;\left[\mathrm{Cu}(\mathrm{L}-\mathrm{phe})(\mathrm{dppz})\left(\mathrm{H}_{2} \mathrm{O}\right)\right]\left(\mathrm{ClO}_{4}\right)$ $(\boldsymbol{\Lambda}) ;\left[\mathrm{Cu}(\mathrm{L}-\mathrm{met})(\mathrm{dppz})\left(\mathrm{H}_{2} \mathrm{O}\right)\right]\left(\mathrm{ClO}_{4}\right)(\boldsymbol{\nabla})$ and $\left[\mathrm{Cu}(\mathrm{L}-\mathrm{lys})(\mathrm{dppz})\left(\mathrm{ClO}_{4}\right)\right]-$ $\left(\mathrm{ClO}_{4}\right)(\diamond)$ at different photoexposure times $(\lambda=365 \mathrm{~nm}$; [complex] $=$ $25 \mu \mathrm{M})$.

are better photocleaver of DNA in comparison to their Lmethionine analogues. The bis-L-lysine complex of copper(II) is cleavage inactive at $365 \mathrm{~nm}$.

The lack of any photocleavage activity of the bpy complex suggests the necessity of both the photoactivatable ligand and DNA binder in the ternary copper(II) structure for observing efficient photo-induced DNA cleavage activity. The positive role of the metal center is clearly observed since the organic conjugates are known to be photo-inactive at red light (Scheme 1). Complexes 2-4 do not show any photo-cleavage activity in the presence of singlet oxygen quencher sodium azide. An enhancement of photocleavage of DNA is observed in $\mathrm{D}_{2} \mathrm{O}$ solvent in which singlet oxygen has longer lifetime. ${ }^{45}$ Hydroxyl radical scavenger DMSO does not show any apparent inhibition in DNA cleavage. Control experiment data suggest the formation of singlet oxygen on photoexposure at $365 \mathrm{~nm}$ (Scheme 3). The photosensitizing effect of the $\{$ (L-lysine)Cu(II) $\}$ moiety is observed in the phen complex 2 in which the photoinactive phen acts as the DNA minor groove binder. The DNA binder heterocyclic bases dpq and dppz have photoactivatable quinoxaline and phenazine moieties. Complexes $\mathbf{3}$ and $\mathbf{4}$ thus show greater photosensitization effect enhancing the overall cleavage activity. We have explored the photocleavage activity of the dpq and dppz complexes at red light of $694 \mathrm{~nm}$ ruby laser using a complex concentration of $50 \mu \mathrm{M}$ with $1 \mathrm{~h}$ exposure time (Table 4, Fig. 5). The DNA cleavage activity at $694 \mathrm{~nm}$ is believed to be metal-assisted in nature involving metal centered electronic bands of lower molar absorbance in the photosensitization process(es) as the ligands individually do not have any visible band at this long wavelength. The ligands alone are cleavage inactive at $694 \mathrm{~nm}$.

\section{Conclusion}

In summary, the ternary copper(II) complexes $[\mathrm{Cu}(\mathrm{L}-$ lys) $\left.\mathrm{B}\left(\mathrm{ClO}_{4}\right)\right]\left(\mathrm{ClO}_{4}\right)(\mathbf{2}-\mathbf{4})$ with a $\mathrm{CuN}_{3} \mathrm{O}_{2}$ coordination display DNA groove binding and show efficient photo-induced DNA cleavage activity on irradiation with UV light of $365 \mathrm{~nm}$ and red light of $694 \mathrm{~nm}$ by a pathway involving the formation of singlet oxygen. The $\{(\mathrm{L}-\mathrm{lys}) \mathrm{Cu}(\mathrm{II})\}$ moiety with a pendant positively charged terminal amino group seems to have photosensitizing effect, while the planar heterocyclic phenanthroline bases are the DNA groove binders. The metal plays an important role by assisting the photosensitization process thus making the complexes as effective photonucleases even at red light of $694 \mathrm{~nm}$. This phenomenon makes the "A-Cu II-B" system (II) significantly different from the organic amino acid-intercalator conjugates "A-B" (I) that show DNA cleavage activity only on UV light irradiation. In addition, the (L-lysine)copper(II) complexes show good solubility in water. In the presence of bio-essential constituents like copper and L-lysine, the present study offers further scope of designing and developing nonporphyrinic metalloorganic compounds for cellular applications in PDT.

\section{Experimental}

\section{Materials and measurements}

The reagents and chemicals were obtained from commercial sources and used as received without further purification. The supercoiled (SC) pUC19 DNA (caesium chloride purified) was procured from Bangalore Genie (India). The calf thymus (CT) DNA, agarose (molecular biology grade), distamycin and ethidium bromide (EB) were from Sigma (USA). Tris(hydroxymethyl)aminomethane- $\mathrm{HCl}$ (Tris-- $\mathrm{HCl}$ ) buffer was prepared using deionized and sonicated triple distilled water. Solvents used for electrochemical and spectral measurements were purified by reported procedures. ${ }^{46}$ Dipyrido[3,2$\left.d: 2^{\prime}, 3^{\prime}-f\right]$ quinoxaline (dpq) and dipyrido[3,2-a:2', $\left.3^{\prime}-c\right]$ phenazene $(\mathrm{dppz})$ ligands were prepared following reported methods. ${ }^{47}$ Ternary copper(II) complexes $\left[\mathrm{Cu}(\mathrm{L}-\mathrm{phe})(\mathrm{dppz})\left(\mathrm{H}_{2} \mathrm{O}\right)\right]\left(\mathrm{ClO}_{4}\right)$ and $\left[\mathrm{Cu}(\mathrm{L}-\mathrm{met})(\mathrm{dppz})\left(\mathrm{H}_{2} \mathrm{O}\right)\right]\left(\mathrm{ClO}_{4}\right)$ were prepared by literature methods. $^{32,35}$

\section{Physical measurements}

The elemental analysis was done using a Thermo Finnigan FLASH EA 1112 CHNS analyzer. The infrared, electronic, fluorescence and circular dichroic spectra were recorded on Perkin Elmer Lambda 35, Perkin Elmer spectrum one 55, Perkin-Elmer LS 50B and JASCO J-716 spectrophotometers, respectively at $25{ }^{\circ} \mathrm{C}$. Magnetic susceptibility data at $298 \mathrm{~K}$ for the polycrystalline samples of the complexes were obtained using a Model 300 Lewis-coil-force magnetometer of George Associates Inc. (Berkeley, USA) make. $\mathrm{Hg}\left[\mathrm{Co}(\mathrm{NCS})_{4}\right]$ was used as a standard. Experimental susceptibility data were corrected for diamagnetic contributions. ${ }^{48}$ Molar conductivity measurements were done using a Control Dynamics (India) conductivity meter. Electrochemical measurements were made at $25^{\circ} \mathrm{C}$ on an EG \& G PAR model 253 VersaStat potentiostat/galvanostat with electrochemical analysis software 270 using a three-electrode setup consisting of a glassy carbon working, platinum wire auxiliary and a saturated calomel reference electrode (SCE) in DMF-Tris- $\mathrm{HCl}$ buffer.

\section{Synthesis of $\left[\mathrm{Cu}(\mathrm{L}-\mathrm{lys}) \mathrm{B}\left(\mathrm{ClO}_{4}\right)\right]\left(\mathrm{ClO}_{4}\right)(1-4)$}

The complexes were prepared by a general synthetic method in which a mixture of L-lysine-hydrochloride $(0.18 \mathrm{~g}, 1.0 \mathrm{mmol})$ and $\mathrm{NaOH}(0.04 \mathrm{~g}, 1.0 \mathrm{mmol})$ in $10 \mathrm{~cm}^{3}$ water was added to an aqueous solution $\left(25 \mathrm{~cm}^{3}\right)$ of $\mathrm{Cu}\left(\mathrm{ClO}_{4}\right)_{2} \cdot 6 \mathrm{H}_{2} \mathrm{O}(0.37 \mathrm{~g}$, $1.0 \mathrm{mmol}$ ) with stirring for $30 \mathrm{~min}$ followed by addition of the corresponding heterocyclic base $[0.15 \mathrm{~g}$, bpy, $\mathbf{1} ; 0.20 \mathrm{~g}$, phen, 2; $0.23 \mathrm{~g}, \mathrm{dpq}, 3 ; 0.29 \mathrm{~g}$, dppz, 4 (1.0 mmol)] taken in $10 \mathrm{~cm}^{3}$ of methanol. The solution was stirred for $4 \mathrm{~h}$ at room temperature and was filtered. Slow evaporation of the filtrate yielded crystalline solid of the product. The solid was isolated and washed with cold aqueous methanol before drying over $\mathrm{P}_{4} \mathrm{O}_{10}$. Yield: $\sim 65 \%$. The complexes showed good solubility in water, methanol, ethanol, DMF and DMSO. Anal. Calc. for $\mathrm{C}_{16} \mathrm{H}_{22} \mathrm{Cl}_{2} \mathrm{CuN}_{4} \mathrm{O}_{10}$ (1): C, 31.9; H, 3.9; N, 9.9. Found: C, 31.7; H, 3.8; N, 9.8\%. IR (KBr phase): 3425br, 3051br, 2946br, 1626s, $1588 \mathrm{~s}, 1497 \mathrm{~m}, 1475 \mathrm{~m}, 1446 \mathrm{~s}, 1399 \mathrm{~m}, 1350 \mathrm{w}, 1138 \mathrm{vs}, 1112 \mathrm{vs}$, $1083 \mathrm{vs}, 772 \mathrm{~s}, 730 \mathrm{~s}, 624 \mathrm{~s}, 559 \mathrm{~m}, 416 \mathrm{~m} \mathrm{~cm}^{-1}$ [br, broad; vs, very strong; s, strong; m, medium; w, weak]. Electronic spectrum in DMF $\left[\lambda / \mathrm{nm}\left(\varepsilon / \mathrm{dm}^{3} \mathrm{~mol}^{-1} \mathrm{~cm}^{-1}\right)\right]: 302$ (7550), 598 (70). Anal. Calc. for $\mathrm{C}_{18} \mathrm{H}_{22} \mathrm{Cl}_{2} \mathrm{CuN}_{4} \mathrm{O}_{10}$ (2): C, 36.6; H, 3.7; N, 9.5. Found: C, 36.8; H, 3.6; N, 9.3\%. IR (KBr phase): 3410br, 3062br, 2948br, $1628 \mathrm{~s}, 1586 \mathrm{~s}, 1521 \mathrm{~s}, 1460 \mathrm{w}, 1430 \mathrm{~s}, 1395 \mathrm{~m}, 1347 \mathrm{w}, 1139 \mathrm{vs}$, $1115 \mathrm{vs}, 1083 \mathrm{vs}, 852 \mathrm{~s}, 722 \mathrm{~s}, 625 \mathrm{~s}, 562 \mathrm{~m}, 432 \mathrm{~m} \mathrm{~cm}^{-1}$. Electronic 
spectrum in DMF $\left[\lambda / \mathrm{nm}\left(\varepsilon / \mathrm{dm}^{3} \mathrm{~mol}^{-1} \mathrm{~cm}^{-1}\right)\right]: 274$ (30500), 294sh, 612 (75). Anal. Calc. for $\mathrm{C}_{20} \mathrm{H}_{22} \mathrm{Cl}_{2} \mathrm{CuN}_{6} \mathrm{O}_{10}$ (3): C, 37.5; H, 3.5; N, 13.1. Found: C, 37.2; H, 3.3; N, 12.8\%. IR ( $\mathrm{KBr}$ phase): $3431 \mathrm{br}, 3083 \mathrm{w}, 2923 \mathrm{~m}, 1615 \mathrm{~s}, 1579 \mathrm{~s}, 1529 \mathrm{w}, 1485 \mathrm{~m}$, $1469 \mathrm{~m}, 1404 \mathrm{~s}, 1386 \mathrm{~s}, 1262 \mathrm{w}, 1142 \mathrm{vs}, 1111 \mathrm{vs}, 1082 \mathrm{vs}, 815 \mathrm{~s}, 776 \mathrm{~s}$, $761 \mathrm{~s}, 729 \mathrm{~s}, 620 \mathrm{~s}, 429 \mathrm{~m} \mathrm{~cm}^{-1}$. Electronic spectrum in DMF $[\lambda / \mathrm{nm}$ $\left.\left(\varepsilon / \mathrm{dm}^{3} \mathrm{~mol}^{-1} \mathrm{~cm}^{-1}\right)\right]: 276$ (10350), 442 (910), 618 (135). Anal. Calc. for $\mathrm{C}_{24} \mathrm{H}_{24} \mathrm{Cl}_{2} \mathrm{CuN}_{4} \mathrm{O}_{10}$ (4): C, 41.7; H, 3.5; N, 12.2. Found: C, $41.5 ; \mathrm{H}, 3.4 ; \mathrm{N}, 11.9 \%$. IR (KBr phase): $3436 \mathrm{br}, 1621 \mathrm{~s}, 1518 \mathrm{~s}$, $1488 \mathrm{~s}, 1465 \mathrm{w}, 1416 \mathrm{~s}, 1358 \mathrm{~m}, 1339 \mathrm{w}, 1140 \mathrm{vs}, 1110 \mathrm{vs}, 1088 \mathrm{vs}$, $817 \mathrm{~s}, 764 \mathrm{~s}, 733 \mathrm{~s}, 625 \mathrm{~m}, 579 \mathrm{w}, 424 \mathrm{~m} \mathrm{~cm}^{-1}$. Electronic spectrum in DMF $\left[\lambda / \mathrm{nm}\left(\varepsilon / \mathrm{dm}^{3} \mathrm{~mol}^{-1} \mathrm{~cm}^{-1}\right)\right]: 276$ (74600), 361 (18900), 376 (16400), 438 (6900), 762 (800).

\section{X-Ray crystallographic procedures}

Single crystals of $\mathbf{2} \cdot 0.5 \mathrm{H}_{2} \mathrm{O}$ were obtained from the motherliquor. Crystal mounting was done on a glass fiber with epoxy cement. All geometric and intensity data were collected at room temperature using an automated Bruker SMART APEX CCD diffractometer equipped with a fine-focus $1.75 \mathrm{~kW}$ sealed tube Mo-K $\alpha$ X-ray source $(\lambda=0.71073 \AA$ ) with increasing $\omega$ (width of $0.3^{\circ}$ per frame) at a scan speed of $12 \mathrm{~s}$ frame ${ }^{-1}$. Intensity data were corrected for Lorentz-polarization effects and for absorption. ${ }^{49}$ The structure was solved and refined with SHELX system of programs. ${ }^{50}$ The hydrogen atoms attached to the carbons were fixed in their calculated positions and refined using a riding model. All non-hydrogen atoms were refined anisotropically.

Crystal data for $2 \cdot 0.5 \mathrm{H}_{2} \mathrm{O}: \mathrm{C}_{18} \mathrm{H}_{23} \mathrm{Cl}_{2} \mathrm{CuN}_{4} \mathrm{O}_{10.5}, M=597.84$, orthorhombic, space group $P 22_{1} 2_{1} 2_{1}$ (no. 19), $a=10.735(5)$, $b=13.574(6), c=33.028(15) \AA, U=4813(4) \AA^{3}, Z=8$, $D_{\mathrm{c}}=1.650 \mathrm{~g} \mathrm{~cm}^{-3}, T=293(2) \mathrm{K}, 1.62 \leq \theta \leq 28.04^{\circ}, \mu=$ $11.93 \mathrm{~cm}^{-1}, F(000)=2448, R 1=0.0693, w R 2=0.1879$ for 7034 reflections with $I>2 \sigma(I)$ and 640 parameters $\left[R 1\left(F^{2}\right)=0.1207\right.$ (all data) $]$. Weighting scheme: $w=1 /\left[\sigma^{2}\left(F_{\mathrm{o}}{ }^{2}\right)+(0.0948 P)^{2}+\right.$ $3.1454 P]$, where $P=\left[F_{\mathrm{o}}{ }^{2}+2 F_{\mathrm{c}}{ }^{2}\right] / 3$. The goodness-of-fit and the

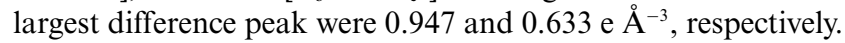
Perspective view of the complex was obtained by ORTEP. ${ }^{51}$

CCDC reference number 262794.

See http://dx.doi.org/10.1039/b506310h for crystallographic data in CIF or other electronic format.

\section{DNA binding and cleavage experiments}

The DNA binding experiments were carried out in Tris- $\mathrm{HCl}$ buffer $(50 \mathrm{mM}$ Tris- $\mathrm{HCl}, \mathrm{pH}$ 7.2) using the complex solution in DMF. The calf thymus (CT) DNA (ca. $350 \mu \mathrm{M} \mathrm{NP}$ ) in the buffer medium gave a ratio of UV absorbance at 260 and $280 \mathrm{~nm}$ of $c a .1 .9$ : 1 suggesting the DNA apparently free from protein. The concentration of DNA was estimated from its absorption intensity at $260 \mathrm{~nm}$ with a known molar absorption coefficient value of $6600 \mathrm{dm}^{3} \mathrm{~mol}^{-1} \mathrm{~cm}^{-1} .{ }^{52}$ Absorption titration experiments were performed by varying the concentration of the CT DNA with the metal complex concentration. Due correction was made for the absorbance of DNA itself. All UV-spectra were recorded after equilibration. The intrinsic binding constant $\left(K_{\mathrm{b}}\right)$ values were obtained from the $[\mathrm{DNA}] /\left(\varepsilon_{\mathrm{a}}-\varepsilon_{\mathrm{f}}\right) v s$. [DNA] plots giving a slope of $1 /\left(\varepsilon_{\mathrm{b}}-\varepsilon_{\mathrm{f}}\right)$ and intercept of $1 / K_{\mathrm{b}}\left(\varepsilon_{\mathrm{b}}-\varepsilon_{\mathrm{f}}\right)$, where $\varepsilon_{\mathrm{a}}, \varepsilon_{\mathrm{b}}$ and $\varepsilon_{\mathrm{f}}$ are apparent absorption coefficient, $\varepsilon$ of the copper(II) complex in its free form and $\varepsilon$ of the complex in the fully DNA-bound form, respectively. ${ }^{53}$

DNA-melting experiments were carried out by monitoring the absorbance $(260 \mathrm{~nm})$ of CT-DNA $(150 \mu \mathrm{M} \mathrm{NP})$ at various temperatures in the absence and presence of the complexes in 2: 1 ratio of DNA and complex with a ramp rate of $0.5^{\circ} \mathrm{C} \mathrm{min}^{-1}$ in phosphate buffer medium ( $\mathrm{pH}$ 6.85) using a Peltier system attached to UV-Visible spectrophotometer. Circular dichroic spectra of DNA were recorded using the complex and CT-DNA concentrations of 25 and $400 \mu \mathrm{M}$, respectively. The apparent binding constant $\left(K_{\text {app }}\right)$ of the complexes 2-4 were determined by fluorescence spectral technique using ethidium bromide (EB) bound CT DNA solution in Tris- $\mathrm{HCl} / \mathrm{NaCl}$ buffer $(\mathrm{pH}, 7.2)$. The fluorescence intensities of $\mathrm{EB}$ at $600 \mathrm{~nm}$ (546 nm excitation) with an increasing amount of the ternary complex concentration were recorded. Ethidium bromide was non-emissive in Trisbuffer medium due to fluorescence quenching of the free EB by the solvent molecules. ${ }^{54}$ In the presence of DNA, EB showed enhanced emission intensity due to its intercalative binding to DNA. A competitive binding of the copper complexes to CT DNA could result in the displacement of EB or quenching of the bound EB by the paramagnetic copper(II) species decreasing its emission intensity.

The extent of SC pUC19 DNA cleavage was monitored by agarose gel electrophoresis. The SC DNA $(0.5 \mu \mathrm{g})$ in $50 \mathrm{mM}$ tris(hydroxymethyl)methane- $\mathrm{HCl}$ (Tris-HCl) buffer $(\mathrm{pH}$ 7.2) containing $50 \mathrm{mM} \mathrm{NaCl}$ was treated with the metal complex (25-100 $\mu \mathrm{M}$ in $2 \mu \mathrm{L}$ of $\mathrm{DMF}$ ) followed by dilution with the buffer to a total volume of $18 \mu \mathrm{L}$. For photo-induced DNA cleavage studies, the reactions were carried out under illuminated conditions using UV source of $365 \mathrm{~nm}(12 \mathrm{~W})$ or pulsed ruby laser of $694 \mathrm{~nm}$ (Lumonics, 1/6 Hz, $20 \mathrm{~ns}$ ). After exposure to the light, each sample was incubated for $1 \mathrm{~h}$ at $37^{\circ} \mathrm{C}$ in dark and analyzed using gel electrophoresis. The inhibition reactions were carried out by adding reagents (distamycin, $75 \mu \mathrm{M}$; DMSO, $4 \mu \mathrm{L}$; sodium azide, $100 \mu \mathrm{M}$; mannitol, $100 \mu \mathrm{M}$; $\mathrm{KI}, 100 \mu \mathrm{M}$; catalase, 1 unit) prior to the addition of the complex. For the $\mathrm{D}_{2} \mathrm{O}$ experiment, this solvent was used for dilution to $18 \mu \mathrm{L}$. Eppendorf and glass vials were used for the $\mathrm{UV}$ and visible light experiments, respectively, at $25{ }^{\circ} \mathrm{C}$ in a dark room. The samples after incubation were added to the loading buffer containing 25\% Bromophenol Blue, $0.25 \%$ xylene cyanol, $30 \%$ glycerol $(3 \mu \mathrm{L})$ and the solution was finally loaded on $0.8 \%$ agarose gel containing $1.0 \mu \mathrm{g} \mathrm{mL}^{-1}$ ethidium bromide. Electrophoresis was carried out in a dark chamber for $2 \mathrm{~h}$ at $60 \mathrm{~V}$ in TAE (Tris-acetate EDTA) buffer. Bands were visualized by UV light and photographed. The extent of DNA cleavage was measured from the intensities of the bands using UVITEC Gel Documentation System. Due corrections were made for the low level of nicked circular (NC) form present in the original supercoiled (SC) DNA sample and for the low affinity of EB binding to SC compared to its NC and linear forms. ${ }^{55}$

\section{Acknowledgements}

We thank the Council of Scientific and Industrial Research (CSIR), New Delhi (01-1841/03/EMR-II) and the Department of Science and Technology (DST), Government of India (SR/S1/IC-10/2004), for financial support; DST for the CCD diffractometer facility; Alexander von Humboldt Foundation, Germany, for donation of an electroanalytical system; Prof. P. K. Das of our department for the ruby laser facility; and the Convener, Bioinformatics Center of our Institute, for database search. A. K. P. is thankful to CSIR, New Delhi, for a fellowship.

\section{References}

1 D. S. Sigman, T. W. Bruice, A. Mazumder and C. L. Sutton, Acc. Chem. Res., 1993, 26, 98; D. S. Sigman, A. Mazumder and D. M. Perrin, Chem. Rev., 1993, 93, 2295; D. S. Sigman, Acc. Chem. Res., 1986, 19, 180 .

2 B. Meunier, Chem. Rev., 1992,92, 1411; G. Pratviel, J. Bernadou and B. Meunier, Adv. Inorg. Chem., 1998, 45, 251; G. Pratviel, J. Bernadou and B. Meunier, Angew. Chem., Int. Ed. Engl., 1995, 34, 746.

3 J. Reedijk, J. Inorg. Biochem., 2001, 86, 89.

4 K. E. Erkkila, D. T. Odom and J. K. Barton, Chem. Rev., 1999, 99, 2777.

5 B. Armitage, Chem. Rev., 1998, 98, 1171; D. R. McMillin and K. M. McNett, Chem. Rev., 1998, 98, 1201.

6 C. Metcalfe and J. A. Thomas, Chem. Soc. Rev., 2003, 32, 215.

7 W. K. Pogozelski and T. D. Tullius, Chem. Rev., 1998, 98, 1089.

8 C. J. Burrows and J. G. Muller, Chem. Rev., 1998, 98, 1109. 
9 S. J. Lippard, Biochemistry, 2003, 42, 2664; E. R. Jamieson and S. J. Lippard, Chem. Rev., 1999, 99, 2467.

10 E. L. Hegg and J. N. Burstyn, Coord. Chem. Rev., 1998, 173, 133; S. E. Wolkenberg and D. L. Boger, Chem. Rev., 2002, 102, 2477.

11 A. Sreedhara and J. A. Cowan, J. Biol. Inorg. Chem., 2001, 6, 337.

12 K. Szacilowski, W. Macyk, A. Drzewiecka-Matuszek, M. Brindell and G. Stochel, Chem. Rev., 2005, 105, 2647.

13 H. T. Chifotides and K. R. Dunbar, Acc. Chem. Res., 2005, 38, 146.

14 H. Umezawa, Prog. Biochem. Pharmacol., 1976, 11, 18; S. E. Wolkenberg and D. L. Boger, Chem. Rev., 2002, 102, 2477; R. P. Hertzberg and P. B. Dervan, J. Am. Chem. Soc., 1982, 104, 313; A. Mukherjee, S. Dhar, M. Nethaji and A. R. Chakravarty, Dalton Trans., 2005, 349; C. J. Thomas, M. M. McCormick, C. Vialas, Z.-F. Tao, C. J. Leitheiser, M. J. Rishel, X. Wu and S. M. Hecht, J. Am. Chem. Soc., 2002, 124, 3875.

15 R. Hettich and H.-J. Schneider, J. Am. Chem. Soc., 1997, 119, 5638.

16 H. Ali and J. E. Van Lier, Chem. Rev., 1999, 99, 2379

17 B. W. Henderson, T. M. Busch, L. A. Vaughan, N. P. Frawley, D. Babich, T. A. Sosa, J. D. Zollo, A. S. Dee, M. T. Cooper, D. A. Bellnier, W. R. Greco and A. R. Oseroff, Cancer Res., 2000, 60, 525.

18 M. C. De Rosa and R. J. Crutchley, Coord. Chem. Rev., 2002, 233234, 351 .

19 E. D. Sternberg, D. Dolphin and C. Brückner, Tetrahedron, 1998, 54, 4151.

20 J. L. Sessler, G. Hemmi, T. D. Mody, T. Murai, A. Burrell and S. W. Young, Acc. Chem. Res., 1994, 27, 43.

21 S. Dhar, D. Senapati, P. K. Das, P. Chattopadhyay, M. Nethaji and A. R. Chakravarty, J. Am. Chem. Soc., 2003, 125, 12118.

22 S. Dhar, D. Senapati, P. A. N. Reddy, P. K. Das and A. R. Chakravarty, Chem. Commun., 2003, 2452.

23 A. K. Patra, S. Dhar, M. Nethaji and A. R. Chakravarty, Chem. Commun., 2003, 1562.

24 S. Dhar, M. Nethaji and A. R. Chakravarty, J. Inorg. Biochem., 2005, 99, 805.

25 S. Dhar and A. R. Chakravarty, Inorg. Chem., 2005, 44, 2582.

26 Á. G. Raso, J. J. Fiol, B. Adrover, V. Moreno, I. Mata, E. Espinosa and E. Molins, J. Inorg. Biochem., 2003, 95, 77; T. K. Roger, T. W. Joel and J. F. Sonya, J. Am. Chem. Soc., 2003, 125, 6656.

27 C.-T. Cheng, V. Lo, J. Chen, W.-C. Chen, C.-Y. Lin, H.-C. Yang and L. Sheh, Bioorg. Med. Chem., 2001, 9, 1493; R. Ren, P. Yang, W. Zheng and Z. Hua, Inorg. Chem., 2000, 39, 5454.

28 D. C. A. John and K. T. Douglas, Biochem. J., 1993, 289, 463.

29 K. P. Mahon, Jr., R. F. Ortiz-Meoz, E. G. Prestwich and S. O. Kelley, Chem. Commun., 2003, 1956.

30 I. Saito and M. Takayama, J. Am. Chem. Soc., 1995, 117, 5590

31 S. V. Kovalenko and I. V. Alabugin, Chem. Commun., 2005, 1444.

32 A. K. Patra, S. Dhar, M. Nethaji and A. R. Chakravarty, Dalton Trans., 2005, 896.

33 D. Herebian and W. S. Sheldrick, J. Chem. Soc., Dalton Trans., 2002, 966.

34 K. Toshima, R. Takano, T. Ozawa and S. Matsumura, Chem. Commun., 2002, 212.
35 P. S. Subramanian, E. Suresh, P. Dastidar, S. Waghmode and D. Srinivas, Inorg. Chem., 2001, 40, 4291.

36 T. Gupta, S. Dhar, M. Nethaji and A. R. Chakravarty, Dalton Trans., 2004, 1896.

37 A. W. Addison, T. N. Rao, J. V. Reedijk and G. C. Verschoor, J. Chem. Soc., Dalton Trans., 1984, 1349.

38 J. K. Barton, A. T. Danishefsky and J. M. Goldberg, J. Am. Chem. Soc., 1984, 106, 2172; T. M. Kelly, A. B. Tossi, D. J. McConnel and T. C. Strekas, Nucleic Acid Res., 1985, 13, 6017; A. Tysoe, R. J. Morgan, A. D. Baker and T. C. Strekas, J. Phys. Chem., 1993, 97, 1707.

39 M. J. Waring, J. Mol. Biol., 1965, 13, 269; J.-B. LePecq and C. Paoletti, J. Mol. Biol., 1967, 27, 87; M. Lee, A. L. Rhodes, M. D. Wyatt, S. Forrow and J. A. Hartley, Biochemistry, 1993, 32, 4237.

40 J. M. Kelly, A. B. Tossi, D. J. McConnel and C. OhUigin, NucleicAcid Res., 1985, 13, 6017; P. Uma Maheswari and M. Palaniandavar, J. Inorg. Biochem., 2004, 98, 219.

41 V. I. Ivanov, L. E. Minchenkova, A. K. Schyolkina and A. I. Poletayer, Biopolymers, 1973, 12, 89.

42 O. Zelenko, J. Gallagher and D. S. Sigman, Angew. Chem., Int. Ed. Engl., 1997, 36, 2776; D. S. Sigman, Biochemistry, 1990, 29, 9097; L. E. Marshall, D. R. Graham, K. A. Reich and D. S. Sigman, Biochemistry, 1981, 20, 244; D. S. Sigman, D. R. Graham, V. D'Aurora and A. M. Stern, J. Biol. Chem., 1979, 254, 12269.

43 M. Pitie, J. D. V. Horn, D. Brion, C. J. Burrows and B. Meunier, Bioconjugate Chem., 2000, 11, 892; L. D. Williams, J. Thivierge and I. H. Goldberg, Nucleic Acids Res., 1988, 16, 11607.

44 J. M. Veal, K. Merchant and R. L. Rill, Nucleic Acids Res., 1991, 19, 338; J. M. Veal and R. L. Rill, Biochemistry, 1991, 30, 1132; J. M. Veal and R. L. Rill, Biochemistry, 1988, 27, 1822.

45 A. U. Khan, J. Phys. Chem., 1976, 80, 2219.

46 D. D. Perrin, W. L. F. Armarego and D. R. Perrin, Purification of Laboratory Chemicals, Pergamon Press, Oxford, 1980.

47 J. E. Dickeson and L. A. Summers, Aust. J. Chem., 1970, 23, 102; E. Amouyal, A. Homsi, J.-C. Chambron and J.-P. Sauvage, J. Chem. Soc., Dalton Trans., 1990, 1841.

48 O. Kahn, Molecular Magnetism, VCH, Weinheim, 1993.

49 N. Walker and D. Stuart, Acta Crystallogr., Sect. A, 1983, 39, 158.

50 G. M. Sheldrick, SHELX-97, Program for crystal structure solution and refinement, University of Göttingen, Göttingen, Germany, 1997.

51 C. K. Johnson, ORTEP III: Report ORNL-5138, Oak Ridge National Laboratory, Oak Ridge, TN.

52 M. E. Reichmann, S. A. Rice, C. A. Thomas and P. Doty, J. Am. Chem. Soc., 1954, 76, 3047.

53 D. E. V. Schmechel and D. M. Crothers, Biopolymers, 1971, 10, 465; A. Wolfe, G. H. Shimer and T. Meehan, Biochemistry, 1987, 26, 6392.

54 J.-B. LePecq and C. Paoletti, J. Mol. Biol., 1967, 27, 87; S. Neidle, Nat. Prod. Rep., 2001, 18, 291.

55 J. Bernadou, G. Pratviel, F. Bennis, M. Girardet and B. Meunier, Biochemistry, 1989, 28, 7268; T. C. Mah and G. A. O'Toole, Trends. Microbiol, 2001, 9, 34; P. S. Stewart and J. W. Costerton, Lancet, 2001, 358, 135. 